\title{
Critical success factors in university-industry collaboration: a bibliometric analysis
}

\author{
Fatores críticos de sucesso na colaboração universidade-empresa: uma análise bibliométrica \\ Factores críticos de éxito en la colaboración universidad-empresa: un análisis bibliométrico
}

Received: 10/01/2021 | Reviewed: 10/07/2021 | Accept: 10/08/2021| Published: 10/10/2021

\author{
Ernani José Fortunato Lisbôa Enke \\ ORCID: https://orcid.org/0000-0002-1321-2198 \\ Universidade Nove de Julho, Brazil \\ E-mail: ernanienke@gmail.com \\ Mauro Luiz Martens \\ ORCID: https://orcid.org/0000-0003-1242-8795 \\ Universidade de São Paulo, Brazil \\ E-mail: mauro.martens@gmail.com \\ Cristina Dai Prá Martens \\ ORCID: https://orcid.org/0000-0003-0955-9786 \\ Universidade Nove de Julho, Brazil \\ E-mail: cristinadpmartens@gmail.com \\ Dariane Beatriz Schoffen Enke \\ ORCID: https://orcid.org/0000-0002-9463-7680 \\ Universidade Estadual Paulista "Júlio de Mesquita Filho", Brazil \\ E-mail: dariane.enke@unesp.br \\ José Celso Contador \\ ORCID: https://orcid.org/0000-0003-4695-3379 \\ Universidade Paulista, Brazil \\ E-mail: celsocontador@terra.com.br \\ Thyago Bachim \\ ORCID: https://orcid.org/0000-0002-8982-545X \\ Universidade Nove de Julho, Brazil \\ E-mail: thyago.bachim@gmail.com \\ Aparecido dos Reis Coutinho \\ ORCID: https://orcid.org/0000-0002-6686-8828 \\ Universidade Nove de Julho, Brazil \\ E-mail: arcoutin@gmail.com \\ Walter Cardoso Satyro \\ ORCID: https://orcid.org/0000-0002-0201-222X \\ Universidade Nove de Julho, Brazil \\ E-mail: satyro.walter@gmail.com
}

\begin{abstract}
Considering the technological development, and particularly the global pandemic of COVID-19, it is essential to align universities and companies as agents in the transformation of society. However, a portion of academic research results does not find application in the productive sector. To better understand such (dis)connection, this study aims to verify in the scientific literature the critical success factors proper to the collaboration between universities and companies. Therefore, a bibliographic survey was carried out in the Scopus and Web of Science databases, considering the period 2000-2020 as temporality. From a quantitative point of view, a bibliometric analysis is presented regarding the year of publication, origin, thematic categories, authorship and co-citation networks, and with a qualitative character, through content analysis, critical factors were identified, with emphasis on trust, commitment, assumption of risks, realistic and well-defined objectives, managerial engagement of project coordinators, university reputation, previous experience in collaboration, communication and organizational culture.
\end{abstract}

Keywords: University-industry; Critical success factors; Bibliometry; Innovation; Networks.

\section{Resumo}

Diante do desenvolvimento tecnológico, e particularmente por conta da pandemia global de COVID-19, é fundamental o alinhamento entre universidades e empresas como agentes nas transformações da sociedade. No entanto, em uma parcela dos resultados das pesquisas acadêmicas não se encontra aplicação imediata no setor produtivo. Para melhor entender esta (des)conexão, este estudo tem por objetivo verificar na literatura científica os fatores críticos de sucesso inerentes à colaboração entre universidades e empresas. Portanto, foi realizado levantamento bibliográfico nas bases de dados Scopus e Web of Science, considerando como temporalidade o período 2000-2020. Sob a ótica quantitativa, é apresentada análise bibliométrica quanto ao ano de publicação, origem, categorias temáticas, autoria e redes de cocitação e, com caráter qualitativo, por meio da análise de conteúdo foram 
identificados fatores críticos, com destaque para confiança, comprometimento, assunção de riscos, objetivos realísticos e bem definidos, engajamento gerencial dos coordenadores de projeto, reputação da universidade, experiência anterior em colaboração, comunicação e cultura organizacional.

Palavras-chave: Universidade-empresa; Fatores críticos de sucesso; Bibliometria; Inovação; Redes.

\section{Resumen}

Dado el desarrollo tecnológico, y particularmente por la pandemia global del COVID-19, es fundamental alinear a las universidades y empresas como agentes en la transformación de la sociedad. Sin embargo, en una parte de los resultados de las investigaciones académicas no existe una aplicación inmediata en el sector productivo. Para comprender mejor esta (des) conexión, este estudio tiene como objetivo verificar en la literatura científica los factores críticos de éxito inherentes a la colaboración entre universidades y empresas. Por ello, se realizó un relevamiento bibliográfico en las bases de datos Scopus y Web of Science, considerando el período 2000-2020 como temporalidad. Desde una perspectiva cuantitativa, se presenta un análisis bibliométrico en cuanto al año de publicación, origen, categorías temáticas, autoría y redes de cocitación y, con carácter cualitativo, mediante análisis de contenido, se identificaron factores críticos, con énfasis en la confianza, el compromiso, la asunción de riesgos. , objetivos realistas y bien definidos, compromiso gerencial de los coordinadores de proyectos, reputación universitaria, experiencia previa en colaboración, comunicación y cultura organizacional.

Palabras clave: Universidad-empresa; Factores críticos de éxito; Bibliometría; Innovación; Redes.

\section{Introduction}

The world was unpredictably affected by the COVID-19 pandemic, when different nations began to fight against such calamity, and agents from universities, companies and governments sought new methods and technologies to continue their normal operations (Siriwardhana et al., 2020). In this global scenario, and considering technological advances, new ideas, innovative approaches and higher levels of multilateral cooperation are needed to face current and emerging economic, social and environmental challenges (OECD \& Eurostat, 2018).

The new technological revolution offers opportunities in line with economic transformations, but it also represents a great challenge to succeed in such an innovative and turbulent business environment (Znagui \& Rahmouni, 2019), where competitors have now similar opportunities, and customers demand highly personalized products (Veza et al., 2015), so that traditional business models come under pressure with the global harmonization of technological standards and reduction of trade barriers (Thoben et al., 2017).

Processes are becoming increasingly dependent on external sources of knowledge (Radosevic et al., 2019), and it is evident that the development of science provides many of the bases for future industrial development (Etzkowitz \& Leydesdorff, 2000). The rapid increase in global knowledge has strengthened the demand for strategic relationships, beyond conventional funding of research projects, with the purpose of playing an important role in industrial, and in turn, economic growth (Al-Shehri et al., 2013). To succeed in this environment, creative partnerships must find innovative responses to the pressure coming from competitors and regulators (Barnes et al., 2000).

Thus, Research and Development (R\&D), considered as one of the main factors that stimulate economic growth in advanced and developing countries (Chen \& Hung, 2016), becomes even more relevant. In this regard, it is noteworthy that the relationships between companies in the production area and cooperation with research institutions and universities tend to reduce spending on $R \& D$, while cooperation with other companies increases spending on R\&D (Lalic et al., 2019).

There are several difficulties in carrying out R\&D in companies, such as lack of resources, lack of strategies, as well as qualified personnel and infrastructure for research development (Conejero, Alves, \& de Lima, 2020; Contreras \& Lujan, 2021; Puangpronpitag, 2019; Silva, 2020). Companies should emphasize their roles in the creation of industrial knowledge, including patents, seeking to improve their innovation mechanisms; however, given the frequency with which technological discoveries occur, only cutting-edge scientific actors can follow and guide on trajectories, and companies should seek support from local universities and research institutes, through closer links with the scientific ecosystem (Xu et al., 2018).

Feng et al. (2018) state that different ways of cooperation can be organized by companies, research institutions and 
universities with more significant research resources, mobilizing them with the purpose of encouraging the development and promotion of key technologies and making the manufacturing industry more intelligent. Studies have shown that over time, the regional impact of universities on the creation of new businesses, the transfer of knowledge and the flow of well-educated people is considerable (Etzkowitz \& Klofsten, 2005).

Knowledge providers are essentially independent research laboratories and universities (Kashyap \& Agrawal, 2019). Due to its ability to create and disseminate knowledge, the modern university is understood as a central agent in innovation systems and in the dynamics of technological updating (Fischer et al., 2019).

The university then undergoes a change from the classic to the entrepreneur model, assuming a role as a center for generating technologies and new forms of business, going beyond traditional research and training (Pogodaeva et al., 2015). Research-oriented universities are increasingly involved in technological updating processes, establishing links with the private sector (Fischer et al., 2019). Companies and universities can interrelate and cooperate in different ways, such as by supporting cooperative research, technology transfer and knowledge transfer (Santoro, 2000).

Industry and academia have different goals. While the industry seeks to develop new products/processes and expand its sales, the university is dedicated to discovering new knowledge and raising funds (Sandberg et al., 2011). However, University-Industry Collaboration (UIC), has long been recognized as a means to promote scientific advancement and achieve goals that benefit all the society (Hernández et al., 2014), being profitable for both parties (Mourtzis et al., 2019), as it supports improvement and innovation in industry, and helps ensure industrial relevance in academic research (Wohlin et al., 2012). In this sense, research activities, within the scope of university-industry interaction, allow researchers to deepen real case studies, enabling the formulation of research questions based on practices in companies, in order to meet their demands (Potts, 1993).

However, universities still need to be more involved with companies, and while there is still a reluctant administration mentality, researchers from higher education institutions often choose essentially theoretical research topics, rather than applied research, keeping gaps between the production of academic research and the development of applied solutions for industry (Kashyap \& Agrawal, 2019).

Thus, universities and research institutes need to improve the conversion of scientific and technological achievements into commercial value through technology transfer or licensing to companies (Xu et al., 2018). Except for a few universities that rise in the global ranking, a large number of institutions have no connection with industry (Kashyap \& Agrawal, 2019). The constant search for research productivity means that the main universities do not use their resources where the impact on local and national communities can be greater (Douglass, 2016).

With regard to research related to university-industry interactions, most of the existing studies correspond to shortterm actions, such as technology transfer (Kashyap \& Agrawal, 2019). According to these authors, the connection of these organizations is limited to internship programs developed by students, but the flow of knowledge, as research and application of this newly created knowledge, is lacking.

According to Fischer, Schaeer and Vonortas (2019), the connection between companies and universities has intensified, but without defined strategies, limited to solving problems with an orientation to the domestic market and without connections to international value chains, suggesting an orientation of the Brazilian innovation system. Although the literature on university-industry collaboration related to the areas of innovation management, technology transfer and commercialization provides insights into various organizational, contextual and relational success factors, gaps still exist (Plewa et al., 2013).

In this context, a deep review of the critical success factors verified in the collaboration between universities and companies can provide an adequate view of this interaction, which helps to minimize some of the challenges existing in the interaction between these actors. Thus, this study aims to verify the key success factors for cooperation between universities and companies, through a bibliometric analysis. 


\section{Methodology}

The methodological approach adopted, consists of a bibliometric literature review, with characteristics of an inductive logic, a quantitative-qualitative review, aimed at understanding the critical success factors inherent to universities-companies collaboration. The study has also a descriptive characteristic, as it describes the development of scientific production regarding the factors present in university-industry relations.

As for the means, the research was guided by a bibliographic survey, through the collection of data from secondary sources, searching for indexed journals and published in English. Searches were carried out from the Scopus and Web of Science database, which has broad coverage for some areas of research, (Zupic \& Čater, 2015), such as business and engineering, being accessed through the CAPES / MEC portal.

First, were performed searches for articles and reviews, without any temporality criteria, in the fields "title", "abstract" or "keyword", using a group of words associated with terms related to university-industry collaboration (A), separated by the Boolean logical operators "OR". From this initial search, were combined terms referring to key factors: critical success factors (B), as shown in Table 1. The searches then represent the sum of A and B, in which the different terms contained in each set of keywords allowed the return of a greater number of articles. It should be noted that, with the purpose of expanding the searches, the symbol "*" was used, as this graphic sign extends the search by including all the words that start before the "**". In addition, it is noteworthy that the terms "UIC" and "U-I-C" refer to the acronyms from university-industry collaboration.

Table 1 - Keyword groups used to carry out the research.

\begin{tabular}{c|c|c}
\multicolumn{1}{c|}{ UNIVERSITY-INDUSTRY COLLABORATION (A) } & CRITICAL SUCCESS FACTORS (B) \\
\hline universit*-industr* & industr*-academ* $^{*}$ & Key Factor* \\
\hline industr*-universit* & UIC & Critical Factor* \\
\hline academ*-industr* & U-I-C & Success Factor* \\
\hline industr*-academ* & - & - \\
\hline
\end{tabular}

Source: Elaborated by the authors (2021).

In the first search, $\mathrm{A}+\mathrm{B}$, the temporal limitation was established including articles as from year 2000. In order to structure the bibliometric maps, were considered data from authors, journals, number of citations, references and keywords, among other information. Also, the VOSviewer software version 1.6.16 (van Eck \& Waltman, 2010) and the Rstudio software version 1.4.1103 (Aria \& Cuccurullo, 2017), both freely accessible, were used. Then, the data were transferred to the Bibliometrix tool, for graphical analysis. A content analysis was performed by verifying the sets of terms shared between documents (Delecroix \& Epstein, 2004). In addition to the bibliometric verification tools, the MS Excel software was used, with cells aligned in columns to insert specific information related to the literature review.

\section{Results and Discussion}

From the initial search (A), which considered only the university-company relationship, the research returned 12,905 publications. It is noteworthy that the first publication is dated March 1877, entitled "The London Industrial University". The article was published by the journal Nature, which addressed a proposal regarding the industrial university theme, highlighting applied science, the related infrastructure and the need to address different areas, such as mathematics, physics and engineering, in addition to the importance of the existence of a faculty focused on research. Thus, this article points out that university-industry collaboration represents the important and for a long-time studied variable, related to a theme of present 
work. Regarding the search for success criteria (B), and also without pre-defined themes and temporality, a search returned 229,859 publications, the first dated from 1916, identified in the Scopus database.

However, according to the selection criteria, both combined searches (A and B), which are the object of this study, returned a total of 147 articles, the first being published in 1988, as shown in Figure 1. In the period delimited between the years 2000-2020, there is an occurrence of growth, with peaks that concentrate the largest number of publications in the years 2000 to the present day, with emphasis on the years 2011, 2016, 2018 and 2020, and with emphasis on the study conducted by Barnes et al. (2002), which accumulates 240 citations in the period. Thus, the analysis of these articles was carried out by reading the titles, abstracts and keywords, and therefore, 60 articles directly linked to the theme/proposal of this research were selected. As an inclusion criterion, only the articles that effectively addressed the relationship between universities and companies were kept as a central theme, with the others being excluded from the sample.

Figure 1 - Annual scientific production.

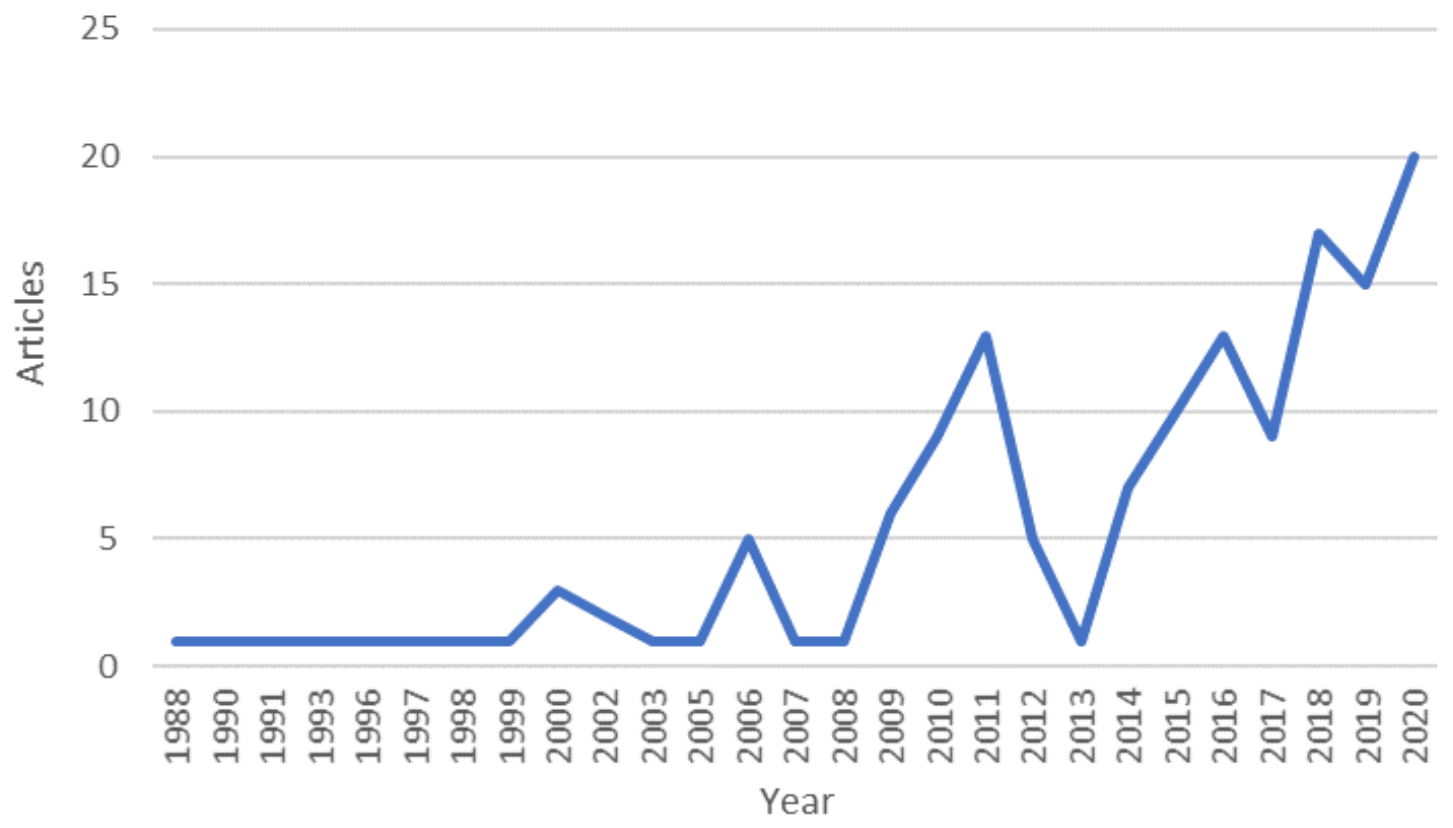

Source: Elaborated by the authors (2021).

In addition, Figure 1 shows that the theme related to university-industry collaboration, with attention to the critical factors inherent to this interaction, has fluctuated in recent years, but with a tendency for an increase in publications, indicating that there are still gaps to be studied.

\subsection{Distribution by subject categories}

The analysis of bibliometric indicators carried out on the 60 publications allows the verification of different subject categories. For better visualization and highlighting the most relevant areas, the categories were reduced to 6 , as shown in Figure 2. 
Figure 2 - Distribution by subject categories.

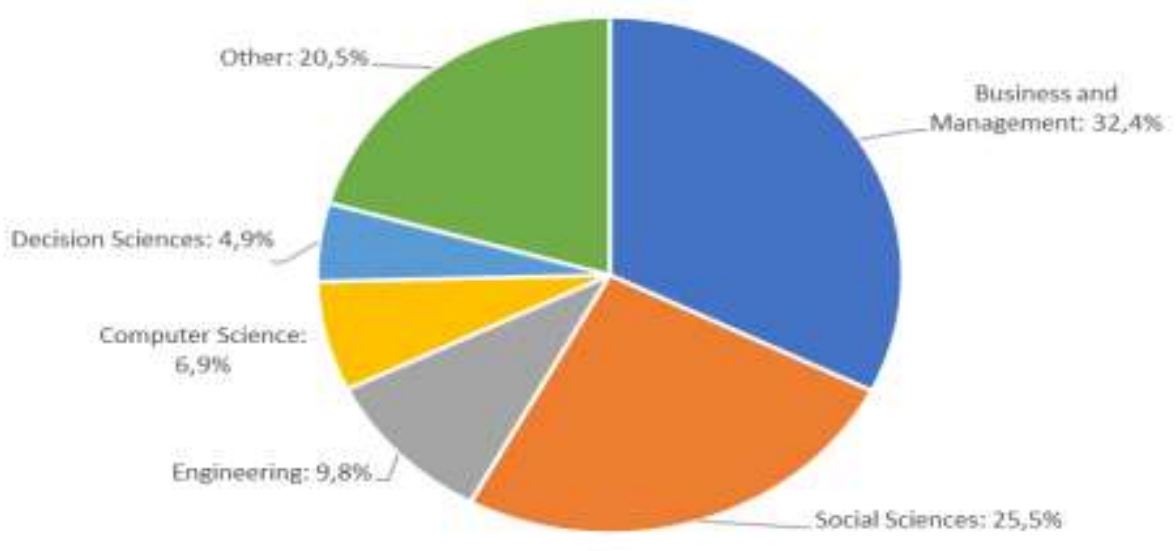

Source: Elaborated by the authors (2021).

From the generated data, it is clear that the articles are connected, especially, with issues related to Business, Management and Accounting (32.4\%), Social Sciences (25.5\%) and Engineering (9.8\%). Computer and Decision Sciences also appear with great representation. The subject categories reflect the basic proposal of university-industry collaboration, whose primary objective is to generate innovation and development of new technologies, products or processes, culminating in new businesses, strongly based on engineering.

\subsection{Analysis of origin - nationality, sources and institutions}

The analysis considered the geographic origin and sources of publications, in addition to identifying institutional data. Articles from 30 countries have been verified, being related to different areas. In this sense, with regard to geographic origin, of the 30 countries identified, 10 concentrate $50 \%$ of publications. The United Kingdom appears with the largest presence with 6 publications and 369 citations, followed by China, Spain and the Netherlands, with 5, 4 and 3 publications respectively. The Netherlands is also the second country with the highest number of citations, with 157.

Regarding institutions, 97 organizations were identified among the publications, and only 12 with more than one publication. The four universities that stand out are Eindhoven University of Technology - Netherlands, University of Salford and University of Strathclyde - United Kingdom, and Wroclaw University of Econnomics - Poland, with 3 publications each, followed by Delft University of Technology - United Kingdom, University Federal de São Carlos - Brazil, Monash University and The University of Adelaide - Australia, Tamkang University - Taiwan, University of Minho - Portugal, and University of Pretoria - South Africa, all with 2 publications each.

From the sample, related to the sources of publication (see Figure 3), 50 different journals were found, with emphasis on the International Journal of Engineering Education, Industry and Higher Education and Science and Public Policy, with 3 publications, and Research Policy, IEEE Software, Technological Forecasting and Social Change and Tertiary Education and Management with 2 publications each. Nonetheless, Figure 3 shows the number of citations per journal, based on the list of references, in which it is possible to observe a change in the relevance of the publication sources. 
Research, Society and Development, v. 10, n. 13, e248101321316, 2021

(CC BY 4.0) | ISSN 2525-3409 | DOI: http://dx.doi.org/10.33448/rsd-v10i13.21316

Figure 3 - Journals with the highest number of citations.

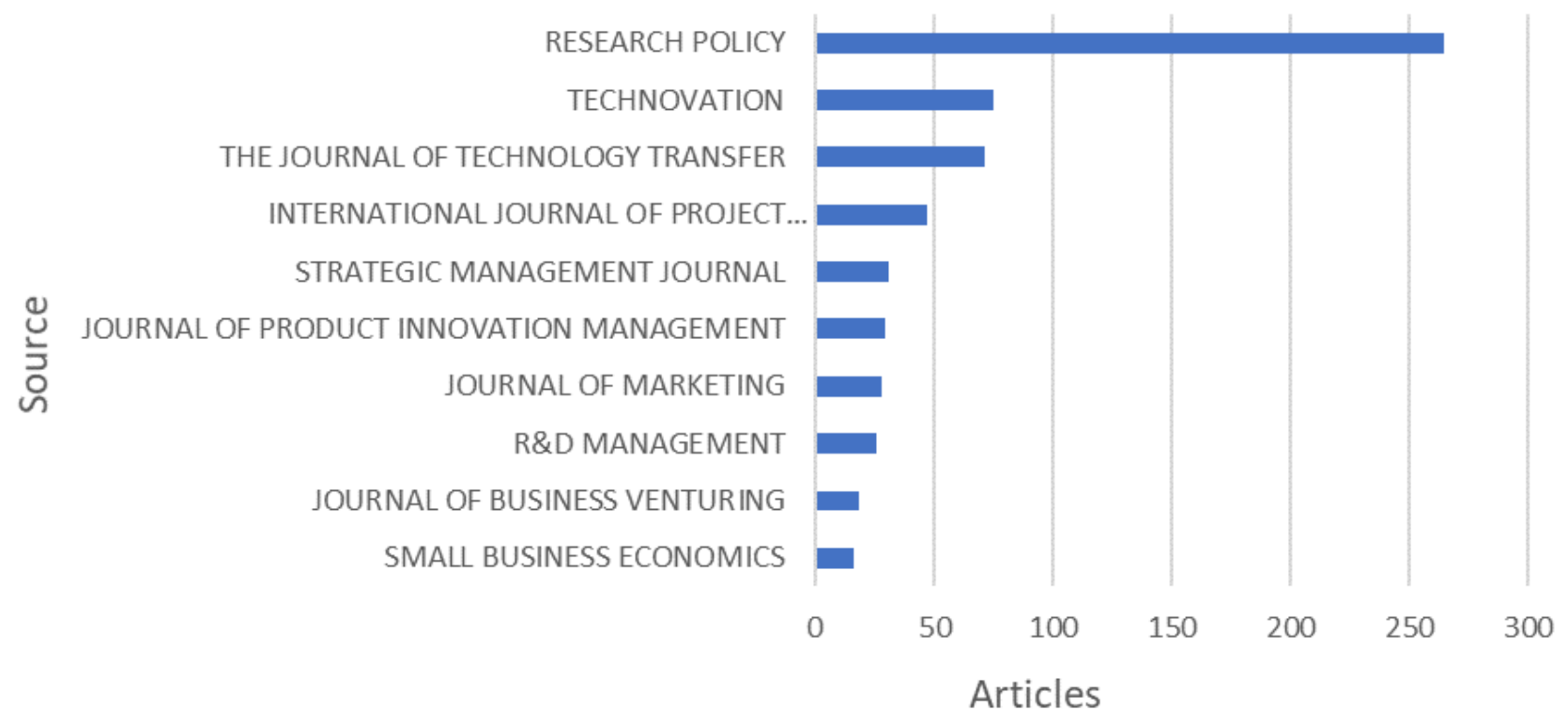

Source: Elaborated by the authors (2021).

Briefly, while only seven journals publish more than one article on the topic, Fig. 3 identifies the number of citations contained in the references of the articles that comprise the sample.

\subsection{Cluster analysis}

According to the co-citation analysis, or cluster analysis, when two different authors are cited in the same article, they are considered to have a link, and the set of such links characterizes clusters of authors. Thus, based on the sample of 60 articles, 3,751 different authors were found, and a minimum limit of 8 citations of each author was determined, considering this to be a value that expresses adequate representation, allowing a reasonable number of authors in the clusters, as shown in Figure 4. 
Figure 4 - Top 50 co-cited authors network.

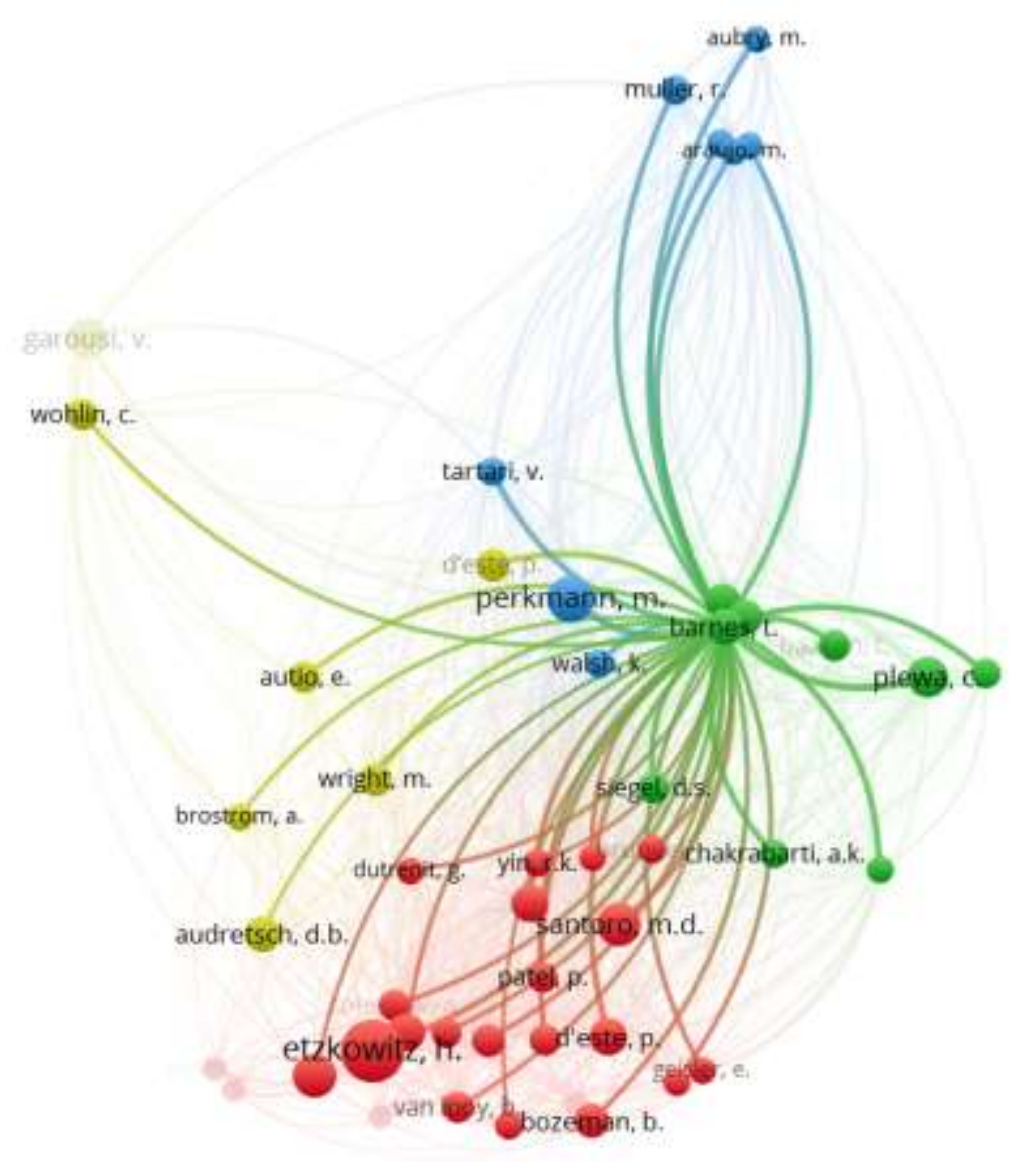

Source: Elaborated by the authors (2021).

The cluster are formed by 50 authors, divided into 4 different streams, which have similarities within each one of them, being differentiated by color. The main stream has 24 authors, being represented by the red cluster, indicating a stronger bond strength between these authors in relation to the other clusters. The circumference indicates a greater number of citations and therefore, the relevance of the authors. In this red cluster, Henry Etzkowitz stands out for being, for about 30 years, an exponent in the theme that involves collaboration between universities and companies, with emphasis on his work on Triple Helix, involving the relations between universities, companies and the government. In the same cluster, Santoro and Chakrabarti (2002) and Thune (2011) also stand out, with important contributions on the subject.

In the green cluster, the work of Barnes et al. $(2002 ; 2006)$ can be highlighted, addressing critical success factors in university-enterprise collaboration from the perspective of project management, as well as Plewa et al. (2013), who investigated relational factors (communication, trust, understanding, individuals) considering the links between university and industry. In the blue cluster, can be highlighted Perkmann et al. (2013) who analyzed individual, organizational and institutional factors and, in the yellow cluster, the work conducted by Wohlin et al. (2012), on critical success factors in collaboration between universities and companies with a focus on software research. The clusters reveal original lines of research, from the beginning of the analyzed period, which continue to influence more contemporary authors in their analyzes concerning the university-industry relationship.

\subsection{Content analysis}

From the sample, 176 different authors were found, but only 6 of them published articles with single authorship. As 
more productive authors, were identified Araújo M. (2020), Baaken T. (2006; 2013), Barnes, T., Pashby, I. and Gibbons, A. (2002; 2006), Fernandes G. (2020), Machado R. (2020), and Pinto E (2020), with 2 publications each. Related to relevance and considering the most cited articles. Table 2 lists the twelve most important publications, showing the number of times that each article was cited (Total Citation - TC) and the annual average number that each article was cited (Average Citation - AC).

Table 2 - Most cited authors.

\begin{tabular}{c|c|c} 
Authors & TC & AC \\
\hline Barnes T. (2002) & 240 & 12 \\
\hline Ratinho T. (2010) & 134 & 11,2 \\
\hline Giuliani E. (2010) & 110 & 9,2 \\
\hline Wohlin C. (2012) & 73 & 7,3 \\
\hline Barnes T.A. (2006) & 73 & 4,6 \\
\hline Plewa C. (2013) & 47 & 5,2 \\
\hline Brostrm A. (2010) & 46 & 3,8 \\
\hline Sandberg A, 2011 & 42 & 3,8 \\
\hline Carayannis E. (2014) & 37 & 4,6 \\
\hline Brem A. (2017) & 34 & 6,8 \\
\hline Belitski M. (2017) & 33 & 6,6 \\
\hline Thune T. (2011) & 33 & 3
\end{tabular}

Source: Elaborated by the authors (2021).

In the search for the most cited articles, the one written by author Tina Barnes has 240 citations, was published in the journal Research Policy, and is entitled Effective university - Industry interaction: A multi-case evaluation of collaborative $R \& D$ projects, with the average of citations per document was 23.33. In order to analyze the content of the articles, was used a network visualization of words, considering only the authors' keywords. Thus, through this feature, 229 different words were identified in the articles, with 27 occurring at least twice, as shown in Figure 5.

The results evidenced the tendency for questions guided by a central theme focused on innovation, which appears in the keywords of 11 publications, with the purpose of addressing objectives related to technology transfer (8 publications), in the subjects relevant to critical success factors (6 publications), and in university-industry collaboration (6 publications). 
Figure 5 - Keywords occurrence.

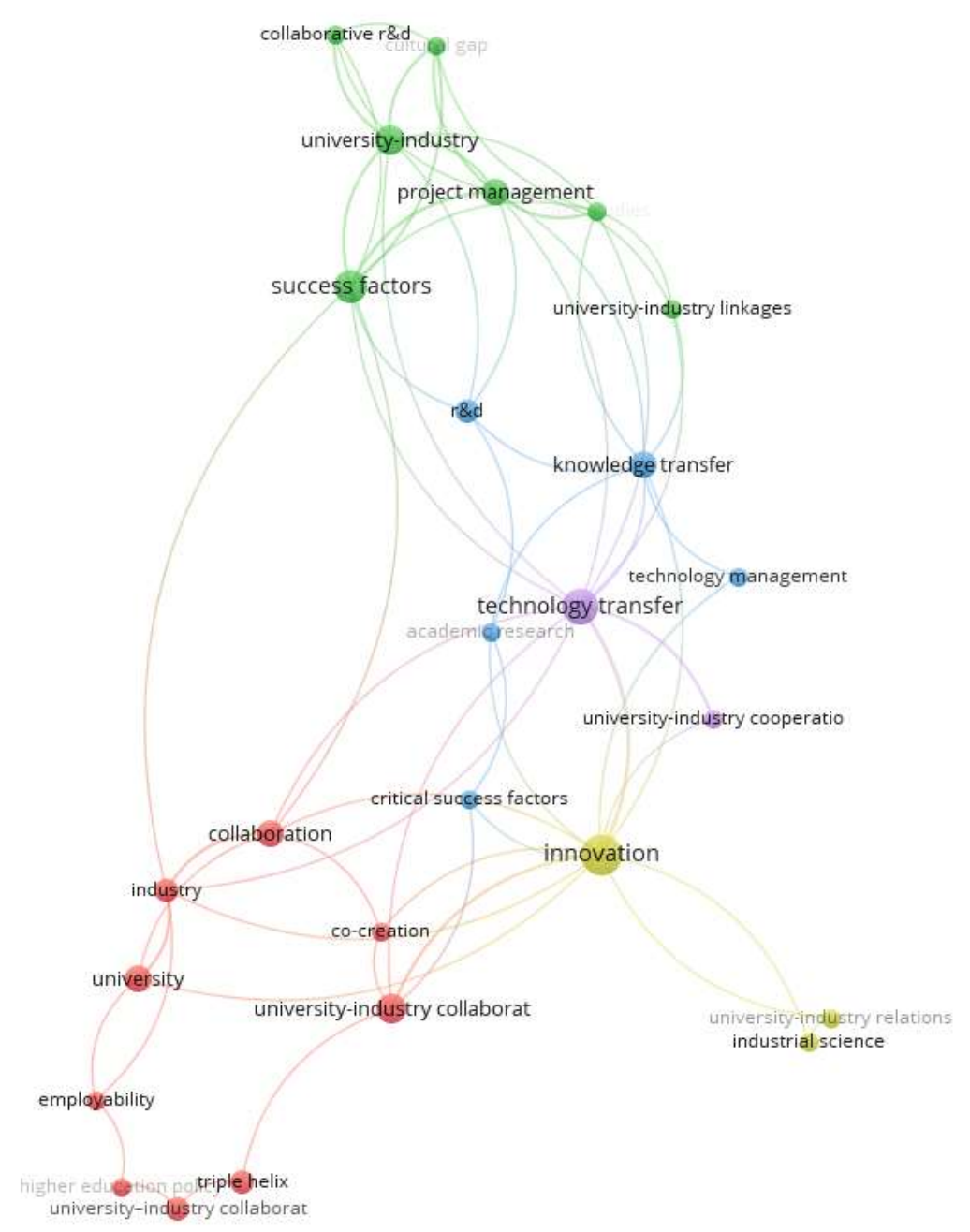

Source: Elaborated by the authors (2021).

Subsequently, when considering the words that occur in the title, abstract or keywords fields, the trend remains the same, with the word innovation appearing 96 times in these fields. In this sense, through the analysis of the articles, it is evident that the basic assumption of university-industry collaboration is aimed at innovation, with a focus on technology transfer. In this sense, authors seek to understand the characteristics of this relationship, under different aspects, including the observation and analysis of critical success factors, and with the purpose of improving this partnership.

\subsubsection{Critical success factors in university-industry collaboration}

With technological transformations taking place at an ever-increasing pace, it is important for the university to come forward to support local companies, with benefits for education, research and innovation (Vijayan et al., 2019). The cooperation between universities and companies represents a key factor for the promotion of technological and industrial advancement (Hernández et al., 2014), being the focus of attention in governments, universities and companies around the world, who seek an effective collaboration for all parties involved (Mosayebi et al., 2020), arousing more and more academic interest in these relationships. Thus, it is presented a synthesis of the content analyzed through the selected publications, with their different purposes, having as its central theme the proposition or observation of key success factors in the collaboration 
between universities and companies.

As the most relevant authors on the subject, Barnes et al. (2002; 2006) identify a series of critical factors, categorizing them by different themes, such as: universal success factors, choice of partner, project management, environmental factors and cultural issues. In this analysis, the factors of trust, flexibility, leadership, learning, commitment, continuity of staff, good personal relationships, complementary experience, previous collaborative experience, experience in project management, adequate resources, good process monitoring, clearly defined responsibilities, corporate stability, adequate skills and training, high quality staff, evidence of mutual benefits, effective communication and clearly defined, realistic, common and complementary objectives.

Among subsequent studies, Sandberg et al. (2011) identify ten success factors during a study involving the telecommunications equipment manufacturer Ericsson and the Chalmers Technical University, both in Sweden. From these factors, five are related to research, namely: management commitment, access to the network, correspondence between employees, communication skills and continuity; and the other five are related to results, namely: orientation to industry issues (real-life), alignment with industry goals, implementation impact, benefits for the industry and innovation.

Other critical success factors were noted by Gustavsson et al. (2016) for university-industry collaborations, aimed at the interaction between graduate programs, focused on doctoral degrees, and industry. Thus, the company's commitment, and the support of its top management, are critical success factors, such as the strategic involvement of the university and the company. The authors also verified other factors, such as: careful recruitment of $\mathrm{PhD}$ students, who are motivated to integrate and mediate knowledge between academia and business; joint formulation of the research project, as a way to properly align the research, so that it becomes beneficial to the university and industry; previous experience of participating companies in research and doctoral teaching; and existence of a key employee in the company.

In the same line, Salimi et al. (2016) address three distinct dimensions, namely: project management, characteristics of supervisor and communication. These dimensions were analyzed from the perspective of six independent variables: level of knowledge transfer, academic publications, whether the knowledge is patented, whether the $\mathrm{PhD}$ candidate (after successful completion of the project) receives a job offer from the university or partner, and whether the collaboration was followed by a new one. The authors showed that successful collaboration is facilitated when there is joint decision-making between the university and the company.

Also related to technology transfer in UIC, Salmi and Torkkeli (2009) examine success factors that affect such transfer, through different categories:

a) Embeddedness of knowledge (in people, tasks, routines and best practices); ability to articulate knowledge; knowledge ambiguity (tacitness, complexity).

b) Knowledge gap between the parties (curvilinear relationship: an optimal distance exists); relative absorptive capacity (similar basic knowledge but different specialized knowledge).

c) Differences in organizational cultures, norms and work values; differences in learning intent and motivation for cooperation; differences in perception of innovation; differences in research objectives; differences in time horizon with respect to expected results; different views on the use and dissemination of new knowledge; different views to commercial viability of different solutions; and the degree of trust and openness.

d) The density of communication; the denseness of social ties; and the difficulty and costs of communication.

In addition to these categories, the authors also address knowledge spillovers to other market actors; private firm's choice of product standard or technology; and industry and regulatory standards.

Mosayebi et al. (2020) conducted a literature review and compiled factors verified by other authors, for example: R\&D expenditure, university's governmental income, non-governmental donations, industry sponsorship for university 
research, scholarships number of researchers, number of publications, projects, reports or patents done in the past, number of industry contracts at the university, number of strategies concerning university-industry cooperation at the university, amount of resources dedicated to support cooperation at university, quality certificates (ISO), prior collaboration with academia, affiliation to any association or research group, number of scientists, structure of employees by occupation and education, number of previous contracts with universities, involvement with the university (former students, professors), firm's perception regarding benefits of cooperation with the university and researcher's perception of the benefits of cooperation with the firm.

In a survey carried out in Portugal by Fernandes et al. (2020), as a literature review, thirty-three benefits related to university-industry collaboration were identified, and sixty-six critical success factors that aim to enable most of these benefits. The factors were identified when analyzing a collaborative R\&D program between the University of Minho (UMinho) and the company Bosch Car Multimedia in Portugal, distributing them in an analytical structure composed of four parameters: by type, term of action, agent and scope.

Another thirteen critical factors were verified by Hanid et al. (2019), who listed: trust, partner reputation, strong teamwork, commitment and leadership skills of the leader, researcher's commitment, having the right person, constant communication, rewards and benefits, financial support, short term results and impact on industry and university, regular meetings, research environment at the university, government support and management support.

Araújo and Teixeira (2014) researched the key factors influencing successful technology transfer between European countries, concluding that employee training on issues related to technology transfer, experience in international or technological projects, and participation in extensive networks, as a rule are the appropriate basis for the transfer of international technology in a Triple-Helix environment, being some also applicable in the regional and national context.

Still in Europe, based on a study involving Spanish companies involved in research and collaborative projects with a large public university in Madrid, Rosendo-Rios et al. (2017) conclud that, from a relationship marketing perspective, directly or indirectly, the relevance of the company's commitment, integration and trust with the university are key factors for university-industry collaboration, and these three relational factors would constitute the basis for satisfaction and sustainable relationships in mutual collaboration, both in the short and long term.

A characterization of success factors related to collaboration between universities and companies was presented by Thune (2011), through a division by categories, as follows: a) contextual factors, including choice of partners and location; b) process factors, emphasizing project management, communication and conflict resolution, as well as social and psychological factors that influence the collaboration climate; and c) organizational factors, which include how collaborations are structured and handled by partners.

In another study, by Leicht et al. (2014) observe different success factors, under the themes: the value of people, the ability of the collaborations to generate value in the long-term, and the symbiotic value and successfule results. As a result, they highlighted the researcher's ability to listen to what the industry wants and understand what is needed; the alignment of the research process with the speed of industry activity; and the ability to present relevant research results, with concise and relevant information for use by the industry.

In a research conducted by Wohlin et al. (2012), were verified sixteen success factors that drive collaboration between industry and academia, related to software research, namely: collaboration champion on site; champion's network within the company; buy-in and support from company management; buy-in and support from industry collaborators; short-term results and impact on industry; organizational stability (industry partner); researcher's visible presence in industry; regular meetings; researcher's relevant expertise; researcher's attitude and social skills; researcher's commitment to contribute to industry needs; research project's organization; research environment at the university; prior experience of industry academia collaboration; trust and short-term result/impact on the university. 
In another aspect, Sjöö and Hellstrom (2019) verify different success factors, such as: resources, university organization, boundary-spanning functions (regular and continuous informal activities at the university, often connected to existing projects), collaborative experience, culture, status centrality and environmental context. Other factors were addressed by Hidalgo and Albors (2011), being: definition of common goals, cooperation, motivation and elimination of technical and legal barriers.

Suh et al. (2019) present the main factors of university-industry cooperation, divided into four dimensions:

a) Human Resources: workforce size; experience of university-industry cooperation; partner selection; executive will; mutual trust; and communication.

b) Technical Resources: staff experience; learning and training; equipment utilization; and reserves of technical.

c) Various environments: budget investment; proximity; facility of university- industry cooperation; commercialization support; and organizational culture.

d) Institutions and systems: support organizational; evaluation/compensation; institutions' regulations; network of participants (associations and associations); and motivation.

Focusing on collaborative innovation, Hadiwattege et al. (2020), carry out a study between universities and companies, identifying 24 critical success factors to be observed by universities, which are linked to three phases of research: beginning, execution and dissemination. In addition to these, another 23 were directed towards the company's behavior.

Zhimin et al. (2016) find seven critical factors including: previous experience, technological capability and trust, referring to the category they identified as cooperative capacity, in addition to another nine referring to the category grouped with cooperative mechanisms, including external support (government and university), applicability of results and risk acceptance. According to the authors, in the initial stages of cooperation, universities pay special attention to problems related to financing and personnel, while companies are concerned, beyond these, with technology. In the intermediate phases, both are concerned with management, and the university starts to give more attention to technological issue. Finally, in the later phases, both are concerned with the product market, and the university also directs its efforts to issues related to intellectual property rights.

In another study carried out in Taiwan, Weng et al. (2016) observe four critical factors linked to organizational heterogeneity: gender, position and nationality of teachers, in addition to diversity in academic experience; concluded that the greater such distinction, the more favorable is the performance of university-industry collaboration. Also, with a sociotechnical perspective, Brem and Radziwon (2017) address three factors: networking, win-win situations (and synergistic effects), as well as a strong problem orientation.

On the other hand, the study by Passarelli et al. (2020) investigated the main factors that impact innovation through the co-development process between universities and small and medium-sized companies; considering the early stages of proof of concept (embryonic stage of technology), identifying factors as academic patent ownership, patent co-ownership, technology readiness, scientific reputation, strategic business units perspective, industrial exploitation and market perspective, Intellectual Property (IP) industrial exploitation and technology perspective, scalability, proximity leverage, technology feasibility and market external assessment.

Therefore, in the context of university-industry collaboration, Table 3 presents a synthesis of the authors discussed above, in relation to the type of study conducted, as well as the origin of the research. 
Table 3 - Studies related to Critical Factors (CF) of university-industry collaboration.

\begin{tabular}{|c|c|c|c|c|c|c|c|}
\hline Author & Year & Origin & $\mathbf{C F}$ & Categories & Approach & $\begin{array}{l}\text { Research } \\
\text { Subjects }\end{array}$ & Focus \\
\hline Barnes, Pashby and Gibbons & $2002 / 2006$ & Literature / Own & 40 & 8 & Case study & Both & \multirow{6}{*}{$\begin{array}{c}\text { UIC } \\
\text { Improvement }\end{array}$} \\
\hline Wohlin et al. & 2012 & Literature / Own & 16 & - & Survey & Both & \\
\hline Leicht, Franz and Molenaar & 2014 & Own & 3 & - & Case study & Both & \\
\hline Weng and Chang & 2016 & Literature & 4 & 1 & Survey & University & \\
\hline Hanid et al. & 2019 & Literature & 28 & - & Survey & University & \\
\hline $\begin{array}{l}\text { Mosayebi, Ghorbani and } \\
\text { Masoomi }\end{array}$ & 2020 & Literature & 20 & - & Survey & - & \\
\hline Zhimin, Zhongpeng and Jin & 2016 & Literature & 16 & 2 & Survey & Both & \multirow{5}{*}{$\begin{array}{l}\text { Collaborative } \\
\text { Innovation }\end{array}$} \\
\hline Brem and Radziwon & 2017 & Literature & 3 & 1 & Case study & Both & \\
\hline Sjoo and Hellstrom & 2019 & Literature & 2 & 7 & $\begin{array}{c}\text { Literature } \\
\text { Review }\end{array}$ & - & \\
\hline Hadiwattege et al. & 2020 & Literature & 50 & 2 & $\begin{array}{l}\text { Survey and } \\
\text { Case study }\end{array}$ & Both & \\
\hline Passarelli et al. & 2020 & Literature & 10 & - & Survey & Both & \\
\hline Hidalgo and Albors & 2011 & Literature & 6 & - & Survey & Both & \multirow{2}{*}{$\begin{array}{l}\text { Technology } \\
\text { Transfer }\end{array}$} \\
\hline Araújo and Teixeira & 2014 & Literature / Own & 11 & - & Survey & Both & \\
\hline Salmi and Torkkeli & 2009 & Literature & 19 & 4 & Case study & Both & \multirow{2}{*}{$\begin{array}{l}\text { Knowledge } \\
\text { Transfer }\end{array}$} \\
\hline $\begin{array}{l}\text { Rosendo-Rios, Ghauri and } \\
\text { Zhang }\end{array}$ & 2016 & Literature & 5 & - & Survey & Firm & \\
\hline $\begin{array}{l}\text { Gustavsson, Nuur and } \\
\text { Söderlind }\end{array}$ & 2016 & Literature / Own & 7 & - & $\begin{array}{l}\text { Survey and } \\
\text { Case study }\end{array}$ & Both & \multirow{2}{*}{$\begin{array}{l}\text { UIC Related } \\
\text { to Graduate } \\
\text { Program }\end{array}$} \\
\hline Salimi, Bekkers and Frenken & 2016 & Literature & 12 & 3 & Survey & University & \\
\hline Sandberg, Pareto and Arts & 2011 & Own & 10 & 2 & Case study & Both & $\begin{array}{l}\text { Collaborative } \\
\text { Research }\end{array}$ \\
\hline Thune & 2011 & Literature / Own & 18 & 3 & Case study & Both & $\begin{array}{l}\text { Partnerships } \\
\text { for Company } \\
\text { Teaching }\end{array}$ \\
\hline Kauppila et al. & 2015 & Literature & 12 & - & Case study & University & $\begin{array}{l}\text { UIC } \\
\text { Analysis }\end{array}$ \\
\hline Suh, Woo, Koh and Jeon & 2019 & Literature & 20 & 4 & Survey & Both & $\begin{array}{l}\text { UIC } \\
\text { Satisfaction }\end{array}$ \\
\hline Fernandes et al. & 2020 & Literature & 66 & 5 & Survey & University & UIC Benefits \\
\hline
\end{tabular}

Notes: The word "both" in the Research Subjects column refers to studies that considered universities and firms. The symbol

"-" was applied for cases where the information was not present in the articles.

Source: Elaborated by the authors (2021).

University-business collaborations are in fact, promoting economic growth by filling the gap between science and business, also contributing to greater qualification and environmental awareness of employees, and having a positive impact on the global socioeconomic context and on the environment (Fernandes et al., 2020).

However, despite several studies conducted, and the constant interest of academia in researching the topic of collaboration between university-industry, the levels of satisfaction among the participants in the university-industry cooperation program are insufficient, requiring further research (Suh et al., 2019). 


\section{Conclusion}

University-industry collaboration allows firms to solve their problems, while providing academia with valuable experience through real-world problems. Both universities and companies have strong expectations regarding the partnerships made, as well as the results that may result from these collaboration processes. Several benefits can be seen in these interactions, through the sharing of knowledge and different resources and facilities, as a way to promote training, innovation and co-creation, providing greater sustainability to universities and helping companies to become more competitive.

These collaborations can further strengthen partnerships that, through technology transfers, development of academic teams and qualified professionals, will result in applied research, more easily focused on market demands.

In order to address the key success factors of these partnerships, this study showed a scenario with different forms of interaction. As a theoretical contribution, a set of key factors is presented, through a literature review, with the purpose of assisting collaboration between these organizations, with space and opportunity for the establishment of networks and creation of platforms that facilitate collaborations in the interaction university-industry.

As a contribution to practice, this research points to a set of critical success factors present in the relationship between universities and firms, which can serve as a basis for decision makers, especially for agents working in related parties, in order to improve collaboration between these, as a way to overcome barriers. Furthermore, it is highlighted that partnerships that develop harmoniously are not necessarily productive partnerships. For the proper development of the partnership, the potential of the partners, who need to act with commitment, must be explored.

In this sense, some key success factors mentioned by different authors stand out: risk taking and sharing; commitment from senior management; managerial engagement of project coordinators; communication, trust; organizational culture; clear definition of objectives and alignment with goals; choice of partner; prior experience and collaborative experience; leadership; university reputation; and conflict resolution.

Several success factors were verified in this study, which showed the need to understand each relationship and its particularities, so that the critical factors deserve more attention, considering that they will be specific to the situation. In this way, the theme can be focused and deepened in different contexts, environments, areas and purposes that guide a certain collaborative relationship. It was also found that there is room for further research aimed at developing structures that can contribute to university-industry collaboration.

In addition, considering the global scenario of rapid and constant technological advances, lately driven by the covid19 pandemic, it is suggested, as future work, to investigate the relationship of the critical factors of collaboration between universities and companies, with the generation of technological innovation, and specific niches such as incubators and startups, among others. Finally, collaboration between universities and firms is characterized as an important source of learning, innovation and value creation, facilitating the sharing and transfer of knowledge and technology, with gains for both organizations.

\section{Acknowledgments}

The authors acknowledge CAPES - Coordenacao de Aperfeicoamento de Pessoal de Nivel Superior of the Federal Government, Brazil, for the resources to make this research. Our gratitude to Mrs. Dinan Dhom Pimentel Sátyro for providing linguistic help. 


\section{References}

Al-Shehri, A., A-b Ebrahim, M., Shafeek, H., Fekry Soliman, M., \& Helmy Abdel-Aziz, M. (2013). Bridging the Gap between University and Industry: Efforts Made at Faculty of Engineering Rabigh - Saudi Arabia. Icaicte, 448-456.

Araújo, C., \& Teixeira, A. (2014). Determinants of International Technology Transfer: An Empirical Analysis of the Enterprise Europe Network. Journal of Technology Management and Innovation, 9(3), 120-134.

Aria, M., \& Cuccurullo, C. (2017). bibliometrix: An R-tool for comprehensive science mapping analysis. Journal of Informetrics, 11(4), 959-975.

Barnes, J. L., Zarrugh, M. Y., Lawrence, D. J., \& McKown, R. L. (2000). A Government-University-Industry Response to Critical Manufacturing Innovation Needs: Virginia's Manufacturing Innovation Center. Industry and Higher Education, 14(2), 73-91.

Barnes, T. A., Pashby, I. R., \& Gibbons, A. M. (2006). Managing collaborative R\&D projects development of a practical management tool. International Journal of Project Management, 24(5), 395-404.

Barnes, T., Pashby, I., \& Gibbons, A. (2002). Effective university - Industry interaction: A multi-case evaluation of collaborative R\&D projects. European Management Journal, 20(3), 272-285.

Brem, A., \& Radziwon, A. (2017). Efficient Triple Helix collaboration fostering local niche innovation projects - A case from Denmark. Technological Forecasting and Social Change, 123, 130-141.

Chen, P.-C., \& Hung, S.-W. (2016). An actor-network perspective on evaluating the R\&D linking efficiency of innovation ecosystems. Technological Forecasting and Social Change, 112, 303-312.

Conejero, M. A., Alves, M.de A. R., \& de Lima, S. C. (2020). An analysis of the critical success factors of social businesses applied to agribusiness: a multicases study. Research, Society and Development, 9(7), 1-30.

Contreras, W. E. B., \& Víctor W. R. L. (2021). Determinants of water and sanitation service satisfaction: The opinion of stakeholders in Pacasmayo. Research, Society and Development, 10 (7), 1-15.

Delecroix, B., \& Epstein, R. (2004). Co-word analysis for the non-scientific information example of Reuters Business Briefings. Data Science Journal, 3(June), 80-87.

Douglass, J. A. (Ed.). (2016). The new flagship university: Changing the paradigm from global ranking to national relevancy. Springer: Cham.

Etzkowitz, H., \& Leydesdorff, L. (2000). The dynamics of innovation: From National Systems and "mode 2" to a Triple Helix of university-industrygovernment relations. Research Policy, 29(2), 109-123.

Feng, L., Zhang, X., \& Zhou, K. (2018). Current problems in China's manufacturing and countermeasures for industry 4.0. EURASIP Journal on Wireless Communications and Networking, 2018(1), 1-6.

Fernandes, G., Araújo, M., Andrade, R., Pinto, E. B., Tereso, A., \& Machado, R. J. (2020). Critical factors for benefits realisation in collaborative universityindustry R\&D programs. International Journal of Project Organisation and Management, 12(1), 1-30.

Fischer, B. B., Schaeffer, P. R., \& Vonortas, N. S. (2019). Evolution of university-industry collaboration in Brazil from a technology upgrading perspective. Technological Forecasting and Social Change, 145(April), 330-340.

Gustavsson, L., Nuur, C., \& Söderlind, J. (2016). An Impact Analysis of Regional Industry-University Interactions: The Case of Industrial PhD Schools. Industry and Higher Education, 30(1), 41-51.

Hadiwattege, C., Senaratne, S., Sandanayake, Y. G., \& Fernando, N. (2020). Merging academic research and industry requirements for innovative construction management practices in Sri Lanka: a study on critical success factors. International Journal of Construction Education and Research.

Hanid, M., Mohamed, O., Othman, M., Danuri, M. S. M., Ye, K. M., \& berawi, M. A. (2019). Critical success factors (CSFs) in university-industry collaboration (UIC) projects in research universities. International Journal of Technology, 10(4), 667-676.

Hernández, M. L. C., Romero, V. V., Rosas, L. V., \& Téllez, R. D. (2014). A decision analytic-value-based methodology for analysing university-industry collaborations. International Journal of Applied Decision Sciences, 7(1), 44-65.

Hidalgo, A., \& Albors, J. (2011). University-industry technology transfer models: An empirical analysis. International Journal of Innovation and Learning, 9(2), 204-223.

Kashyap, A., \& Agrawal, R. (2019). Academia a new knowledge supplier to the industry! Uncovering barriers in the process. Journal of Advances in Management Research, 16(5), 715-733.

Lalic, B., Todorovic, T., Medic, N., Bogojevic, B., Ciric, D., \& Marjanovic, U. (2019). The impact of inter-organizational cooperation on R\&D expenditure of manufacturing companies. Procedia Manufacturing, 39(2019), 1401-1406.

Leicht, R. M., Franz, B., \& Molenaar, K. R. (2014). Successful university research programs with extensive industry involvement. Practice Periodical on Structural Design and Construction, 19(1), 57-62.

Mosayebi, A., Ghorbani, S., \& Masoomi, B. (2020). Applying fuzzy delphi and best-worst method for identifying and prioritizing key factors affecting on university-industry collaboration. Decision Science Letters, 9(1), 107-118. 
Mourtzis, D., Tsakalos, D., Xanthi, F., \& Zogopoulos, V. (2019). Optimization of highly automated production line: An advanced engineering educational approach. Procedia Manufacturing, 31, 45-51.

OECD/Eurostat (2018), Oslo Manual 2018: Guidelines for Collecting, Reporting and Using Data on Innovation, 4th Edition, The Measurement of Scientific, Technological and Innovation Activities, OECD Publishing, Paris/Eurostat, Luxembourg.

Passarelli, M., Landi, G. C., Cariola, A., \& Sciarelli, M. (2020). Open innovation in the new context of proof of concepts: evidence from Italy. European Journal of Innovation Management, 24(3), 735-755.

Perkmann, M., Tartari, V., McKelvey, M., Autio, E., Broström, A., D’Este, P., Fini, R., Geuna, A., Grimaldi, R., Hughes, A., Krabel, S., Kitson, M., Llerena, P., Lissoni, F., Salter, A., \& Sobrero, M. (2013). Academic engagement and commercialisation: A review of the literature on university-industry relations. Research Policy, 42(2), 423-442.

Plewa, C., Korff, N., Baaken, T., \& Macpherson, G. (2013). University-industry linkage evolution: An empirical investigation of relational success factors. $R$ and D Management, 43(4), 365-380.

Pogodaeva, T., Zhaparova, D., \& Efremova, I. (2015). Changing Role of the University in Innovation Development: New Challenges for Russian Regions. Procedia - Social and Behavioral Sciences, 214, 359-367.

Potts, C. (1993). Software-Engineering Research Revisited. IEEE Software, 10(5), 19-28.

Puangpronpitag, S. (2019). Triple Helix Model and Knowledge-Based Entrepreneurship in Regional Engagement: A Case Study of Thai and UK Universities. Procedia Computer Science, 158, 565-572.

Rosendo-Rios, V., Ghauri, P. N., \& Zhang, Y. (2017). Empirical analysis of the key factors that can contribute to university-industry cooperational success from a relationship marketing approach. European Journal of International Management, 10(6), 647-677.

Salimi, N., Bekkers, R., \& Frenken, K. (2016). Success factors in university-industry PhD projects. Science and Public Policy, 43(6), 812-830.

Salmi, P., \& Torkkeli, M. (2009). Success factors of interorganisational knowledge transfer: A case of a collaborative public private R\&D project. International Journal of Business Innovation and Research, 3(2), 109-125.

Sandberg, A., Pareto, L., \& Arts, T. (2011). Agile collaborative research: Action principles for industry-academia collaboration. IEEE Software, 28(4), 74-83.

Santoro, M. D. (2000). Success breeds success: The linkage between relationship intensity and tangible outcomes in industry-university collaborative ventures. Journal of High Technology Management Research, 11(2), 255-273.

Santoro, M. D., \& Chakrabarti, A. K. (2002). Firm size and technology centrality in industry-university interactions. Research Policy, 31(7), 1163-1180.

Silva, A. C. (2020). Organizational change: a transition model. Research, Society and Development, 9(6), 1-22.

Siriwardhana, Y., De Alwis, C., Gur, G., Ylianttila, M., \& Liyanage, M. (2020). The Fight against COVID-19 Pandemic with 5G Technologies. IEEE Engineering Management Review, 48(3), 72-84.

Sjöö, K., \& Hellström, T. (2019). University-industry collaboration: A literature review and synthesis. Industry and Higher Education, 33(4), 275-285.

Suh, Y., Woo, C., Koh, J., \& Jeon, J. (2019). Analysing the satisfaction of university-industry cooperation efforts based on the Kano model: A Korean case. Technological Forecasting and Social Change, 148, 119740.

Thoben, K.-D., Wiesner, S. A., \& Wuest, T. (2017). "Industrie 4.0" and smart manufacturing-a review of research issues and application examples. International Journal of Automation Technology, 11(1), 4-16.

Thune, T. (2011). Success Factors in Higher Education-Industry Collaboration: A case study of collaboration in the engineering field. Tertiary Education and Management, 17(1), 31-50.

Van Eck, N. J., \& Waltman, L. (2010). Software survey: VOSviewer, a computer program for bibliometric mapping. Scientometrics, 84(2), 523-538.

Veza, I., Gjeldum, N., \& Mladineo, M. (2015). Lean Learning Factory at FESB - University of Split. Procedia CIRP, 32, 132-137.

Vijayan, K. K., Mork, O. J., \& Giske, L. A. L. (2019). Integration of a Case Study into Learning Factory for Future Research. Procedia Manufacturing, 31, $258-263$.

Weng, H.-J., \& Chang, D.-F. (2016). Determining the influence of heterogeneity in graduate institutions on university-industry collaboration policy in Taiwan. Asia Pacific Education Review, 17(3), 489-499.

Wohlin, C., Aurum, A., Angelis, L., Phillips, L., Dittrich, Y., Gorschek, T., Grahn, H., Henningsson, K., Kågström, S., Low, G., Rovegard, P., Tomaszewski, P., Van Toorn, C., \& Winter, J. (2012). The success factors powering industry-academia collaboration. IEEE Software, 29(2), 67-73.

Xu, G., Wu, Y., Minshall, T., \& Zhou, Y. (2018). Exploring innovation ecosystems across science, technology, and business: A case of 3D printing in China. Technological Forecasting and Social Change, 136, 208-221.

Zhimin, G., Zhongpeng, C., \& Jin, T. (2016). Empirical Study of the Role of Government Support and Success Factors in Industry-University-Institute Cooperation. Chinese Education and Society, 49(3), 166-181.

Znagui, Z., \& Rahmouni, B. (2019). What ecosystem model to support the creation of social innovation technopoles? Procedia Computer Science, 158, $877-$ 884 .

Zupic, I., \& Čater, T. (2015). Bibliometric Methods in Management and Organization. Organizational Research Methods, 18(3), 429-472. 